Seoul Journal of Business

Volume 3, Number 1

\title{
Cross-Cultural Adjustment of Expatriates: Theory \& Research Findings on American and Japanese Expatriates
}

\author{
Chang, Young-Chul \\ Executive Director HR Institute LG Academy
}

\begin{abstract}
Theories and research findings on expatriate adjustment were examined to gain a better understanding of the adjustment process. Empirical studies have been limited to focusing on the failure rates of expatriates rather than their adjustment capacity in foreign societies. Few studies have attempted to assess the level of adjustment for both American and Japanese expatriates in the same cultural environment. Future studies need to investigate how much more well-adjusted one group of expatriates is over another in different cultural settings, the differences in their adjustment to the different facets of cross-cultural adjustment, and the factors that enable one group to outperform the other group.
\end{abstract}

\section{I . Introduction}

Expatriates confront numerous obstacles, both in the overseas workplace and in the foreign society in which they reside: culture shock, differences in work-related norms, isolation, homesickness, differences in housing, language, customs, sex roles, and cost of living, to name a few (Mendenhall, Dunbar, and Oddou, 1987). Given the barrage of cross- cultural obstacles that every expatriate must confront, it is in the interest of the expatriates to understand what factors influence their adjustment and how well they adjust. Because the cost of

* Three anonymous reviewers for this journal provided valuable comments and suggestions in preparing the revision. 
maintaining a manager in an overseas post averages about US\$250,000 per year (Black, 1988; Misa and Fabricatore, 1979), companies can also benefit greatly from learning more about the phenomenon of adjustment.

Much of the general interest in cross-cultural adjustment began with Lysgaard's (1955) study of the adjustment of Norweigian students who received Fulbright scholarships. While research has been going on for over 30 years, many shortcomings and gaps still remain. According to Brein and David (1971), one of the major problems in understanding the topic of expatriate adjustment is that the approaches of various investigators have been very divergent. Thus, it is either difficult to interrelate their findings or to develop any consistency among the factors deemed relevant to intercultural adjustment.

The limited representativeness of the research samples also poses another problem. Church (1982) noted that most of the research he reviewed used students as the sample population or examined the adjustment of Americans in foreign countries. Additionally, until recently, few studies had examined the adjustment of American businessmen or expatriate employees serving in temporary international assignments (e.g., Baker and Ivancevich, 1971; Black, 1988; Earley, 1987; Hawes and Kealey, 1981; Lee and Larwood, 1983; Misa and Fabricatore, 1979; Tung, 1982). The adjustment of foreign employees has received even less attention.

A further limitation lies in the choice of research respondents. Some studies have asked human resource decision makers for their opinions about important antecedents to cross-cultural adjustment of international personnel (Tung, 1981; 1988). These empirical studies have provided important but limited results (Black and Gregersen, 1991), as assessing the determinants of cross-cultural adjustment through a third party's view may fail to reflect the actual situation faced by the expatriate. Relatively few empirical studies have examined the problem from the perspective of actual expatriates.

As the level of internationalization of the business world increases, the need for managers to live and work in foreign countries also increases. It is therefore important to gain a better understanding of the adjustment process. For companies attempting to compete in an international business environment, understanding and managing effective adjustment of expatriate employees has become an important personnel issue.

The main purposes of this study are (1) to review the theoretical and empirical development of the concept of cross-cultural adjustment, (2) to examine critical dimensions of the corss-cultural adjustment concept, (3) to understand the 
diversity and complexity of the adjustment process and (4) to identify critical issues in the studies of cross-cultural adjustment by reviewing studies reporting the adjustment capabilities and patterns of two "culturally distant" groups, American and Japanese expatriates. Through comparison and contrast of these two groups, both universal adjustment issues and culture-specific adjustment issues are expected to manifest.

This paper will be organized as follows. First, the previous literature on cross-cultural adjustment will be reviewed, with specific interest on the conceptualization and the existing theories and models of cross-cultural adjustment. The determinants of adjustment will also be examined. Then, the adjustment issues reported and discussed in past studies involving samples of American and Japanese expatriates will be examined.

\section{II . Concept of Adjustment}

\section{Definitions of Adjustment}

A major difficulty with research on culture contact has been the lack of clarity about what constitutes "adjustment" (Brein and David, 1971; Church, 1982) and how it changes over time. Before proceeding further, it is important to define what is meant by adjustment.

Adjustment has been conceptualized in basically two different ways. The first conceptualization relates to the degree of psychological adjustment experienced by the individual or the degree of psychological comfort and familiarity that individual has for the new environment (Mendenhall and Oddou, 1985). Some scholars have tried to measure this adjustment directly (Black, 1988; Earley, 1987) while others have viewed other variables as appropriate proxies. Numerous variables that have been utilized as indices of "adjustment" include satisfaction (Abe and Wiseman, 1983; Torbiorn, 1982; Gudykunst, et. al., 1977), feelings of acceptance and coping with everyday activities (Brislin, 1981), as well as acquisition of culturally appropriate behavior and skills (Bochner, Lin, and McLeod, 1980; Furnham and Bochner, 1986).

The second conceptualization of degree of adjustment has focused on more objective data, such as performance ratings obtained from independent sources (Earley, 1987; Hawes and Kealey, 1981). However, some scholars have maintained that adjustment is a construct of the individual's affective 
psychological response to the new environment and that variables, such as job performance and turnover, should not be thought of as "objective measures of adjustment," but rather as outcome variables that might be influenced by the degree of adjustment (Mendenhall and Oddou, 1985; Black, 1988).

Searle and Ward (1990), however, argued that adjustment during cross-cultural transitions can be broadly divided into two categories: psychological adjustment and sociocultural adjustment. Here, psychological adjustment is the feeling of well-being and satisfaction and sociocultural adjustment is the ability to "fit in" and negotiate interactive aspects of the new culture.

\section{Dimensions of Cross-Cultural Adjustment}

Even when the definition of adjustment is specified as the degree of psychological comfort and familiarity an individual feels for the new culture and situation, researchers have disagreed as to whether adjustment is a unitary or multi-faceted phenomenon. Researchers who have viewed adjustment as a singular, unified construct have generally focused on an individual's adjustment to the general environment or culture of the foreign country (Torbiorn, 1982; Tung, 1988). Other researchers have taken a more multi-faceted perspective of adjustment, focusing on the work situation and the general environment (Black, 1988). Still other researchers have focused on adjustment to interacting with host nationals, separating interactions with host nationals from other aspects of the general environment, such as food, weather, and transportation system (Brein and David, 1971; Hawes and Kealey, 1981). Recently, Black and Stephens (1989) and Black (1990a, c) argued for and found empirical support for three facets of cross-cultural adjustment: work adjustment, interaction adjustment, and general adjustment. The above literature suggests that adjustment could be measured in terms of adjustment to the general environment, to work situation, and to interaction with host nationals. The reason for distinguishing among these three facets of adjustment is that not all important factors are related equally, or even at all, to all three adjustment dimensions. Different antecedents were related to different facets of adjustment (Black \& Gregersen, 1991). Although these major dimensions were developed initially based on the experience of American managers overseas, it is interesting to note that research (Black, 1988; 1990a; Black \& Gregersen, 1991) has found strong evidence that Japanese managers sent on foreign assignments experienced the same three facets of adjustment. 


\section{Adjustment to the Job}

According to Black, Gregersen, \& Mendenhall (1992), adjustment to the job is the easiest of the three dimensions of adjustment for both American and Japanese expatriate managers, primarily because job adjustment is aided by similarities in procedures, policies, and requirements of the foreign operation and home-country operation tasks. However, adjustment to this dimension is not as smooth as imagined. Effort is still needed to adjust because the corporate culture of the foreign subsidiary may differ from what the expatriate was used to back home. In addition, differences in national culture may also dictate different ways of doing things.

\section{Adjustment to Interaction}

For American and Japanese expatriates, this is generally the most difficult dimension of adjustment, primarily because it is in interactions with host-country nationals that differences in perceptions, beliefs, and values emerge. Different cultures have different rules to guide the proper functioning of individuals within their respective societies. As a result of all these differences, conflicts and misunderstandings may arise between newcomers entering the foreign culture and the host nationals. This can lead to anxiety, anger and depression, which ultimately hinder adjustment. This problem is especially acute, given that values and assumptions are those aspects of the culture that are not directly visible to outsiders and are, therefore, the most difficult to understand. To come to grips with these values and assumptions, the expatriate must live and work in the foreign culture for a substantially long period of time.

\section{Adjustment to the General Non-Work Environment}

This is the dimension that typically has been the focus of many cross-cultural adjustment researchers (Torbiorn, 1982; Hawes and Kealey, 1981). This dimension includes such issues as food, housing, shopping, and health care. In terms of difficulty, this dimension generally falls between job and interaction adjustment for both Japanese and American managers.

\section{Review of Theory and Research on Adjustment}

In the last few decades, research in the area of cross-cultural adjustment, 
concentrating on such diverse groups as immigrants, refugees, and sojourners, has flourished. The expanding field, however, has been plagued by a variety of problems, in particular, the lack of consensus across studies as to the appropriate theoretical framework for adjustment and the lack of agreement on definitions of key constructs. A review of the literature shows that there are various models, frameworks, and perspectives on cross-cultural adjustment existing in the field.

\section{U-Curve Function of Adjustment}

Cross-cultural adjustment takes place over time. People do not adjust to living and working in a foreign culture immediately. Lysgaard (1955) was one of the first to suggest that sojourners pass through a series of stages of adjustment that take the form of a U-curve. The U-curve essentially describes the course of adjustment of sojourners abroad. According to this view, people tend to start off their sojourn in good shape. Their well-being may even increase a little with entry into a new culture. Later, as they come to grips with the foreign culture, their sense of well-being declines. Then as they learn to cope, they come to feel better about themselves and the world around them. The U-shaped pattern has been reported for expatriates and students, among others, residing in a particular location on a temporary basis.

However, the U-curve hypothesis has received surprisingly little empirical support. There is a good deal of anecdotal evidence, but Church (1982: 542), in his review of the literature, concluded that evidence for the U-curve is "weak, inconclusive, and overgeneralized." There are, according to him, about as many studies confirming as disconfirming the U-curve, and the most comprehensive study to date (Klineberg and Hull, 1979) found no support for the U-curve hypothesis. Furnham and Bochner (1986: 132) point out that the rate of cultural learning is not the same across sojourners and that the U-curve hypothesis is too vague and too generalized to be of much use in predicting or understanding sojourner adjustment." Gullick (1988) suggests that cultural adaptation is best viewed as a learning process depicted by step or cyclical models rather than U-shaped diagrams.

\section{W-Curve Function of Adjustment}

Initially, because studies were limited to the sojourner's adjustment within the 
host culture, researchers reported a U-curve function of adjustment. The U-curve, however, has been extended by Gullahorn \& Gullahorn (1963) into a W-curve. This is essentially an extension of the single U-curve to a double U-curve. It encompasses both the sojourner's adaptation to a foreign culture and his or her readjustment to home culture. The $\mathrm{W}$-curve may be a more comprehensive description of the adjustment process. It represents the adjustment of the sojourner along a temporal dimension. In a very general manner, the sojourner tends to undergo a decline in adjustment shortly after entering a foreign culture, which is followed by a recovery stage with a resultant increase in adjustment; then, on returning home, the sojourner undergoes another decrease in adjustment followed by a second stage of recovery.

\section{Culture Shock}

Rather than describing adjustment strictly in terms of curve functions, other researchers (Hall, 1959; Oberg, 1960; Bock, 1970; Lundstedt, 1963) have portrayed adjustment in verbal terms as a series of sequential stages. Culture shock is a phenomenon that occurs during this adjusment process. Although differing with respect to the numbers and kinds of stages, culture shock bears a close resemblance to one or more aspects of the $U$ and $\mathrm{W}$ phenomena.

According to Oberg (1960), culture shock refers to the disorientation and anxiety experienced by sojourners in cross-cultural transition. It is the natural outcome of adjusting to a new culture-its customs, language, norms, etc.-and usually includes such symptoms as anxiety, irritability, and psychological discomfort.

There are four key stages in the overseas experience reflecting an individual's psychological and cultural adjustment to a new environment. Stage one is a period of incubation, during which time the sojourner may feel highly elated. Stage two is a period of crisis resulting from the genuine difficulties that the sojourner may begin to encounter in a different culture. At this stage, the activities of daily living that has been previously taken for granted become insurmountable problems. Culture shock occurs at the transition between stage two and stage three, when the person has received the maximum amount of negative feedback but as yet has very little idea as to what is appropriate behavior. (In the U-curve, this is represented by the trough in the adjustment curve.) Stage three is a period of recovery in which the sojourner begins to understand some of the cues of the host culture. Stage four is the complete 
period of recovery in which the sojourner accepts the host culture. (Researchers found that not all individual experienced the same degree of culture shock.)

Although different writers may emphasize different aspects of culture shock, their descriptions of the causes, content and symptoms of this phenomenon are all quite similar. Hall (1959: 156) defined culture shock as a removal or distortion of many of the familiar cues one encounters at home and the substitution for them of other cues which are strange. Bock (1970) described culture shock as a disturbing feeling of disorientation and helplessness resulting from exposure to alien society. Lundstedt (1963) described culture shock as a reaction to stress in an environment where the satisfaction of important psychological and physical demands is usually uncertain and difficult to foresee.

\section{Clinical Model of Adjustment}

Clinical models have conventionally drawn on the role of personality, life events or changes, losses, and social supports, all which facilitate or impede the adjustment process (e.g., Adelman, 1988; Feinstein and Ward, 1990; Fontaine, 1986). Unfortunately, research in this domain has not been well-integrated. Early research considered a host of personality traits in relation to psychological and social adaptation. Such traits include authoritarianism (Brislin, 1981; Mischel, 1965; David, 1971) and flexibility (David, 1971; Gullahorn and Gullahorn, 1963; Sewell and Davidsen, 1961). Later research, however, has suggested that these variables may interact with characteristics of the host culture (Searle and Ward, 1990; Church, 1982). As an attempt to synthesize clinically oriented research on the cross-cultural adjustment process, Searle \& Ward (1990) suggested that the effects of life changes (sojourns) should be examined jointly with the nature of the changes (e.g., intensity, cultural context) and the characteristics of the individual (e.g., personality) within a stress and coping framework. According to them, it is the interaction of these three variables that determine adjustment to a foreign milieu.

\section{Social Skill Learning Model of Adjustment}

The social skill learning perspective is probably the most popular in current research on cross-cultural transitions, as is exemplified by Brislin's (1981) cultural learning approach and Furnham and Bochner's (1986) social skills model. This perspective emphasizes the acquisition of culturally appropriate skills and 
behaviors through contact with host nationals, cross-cultural experience and training (e.g., Furnham and Bochner, 1982). Much of the research on the impact of cross-cultural experience has examined its effects on psychological well-being. Variables that were studied include previous experience (Church, 1982; Prutti, 1978) and the impact of cross-cultural training (e.g., Fiedler, Mitchell, and Triandis, 1971; Randolph, Landis, and Tzeng, 1977). The skill learning approaches acknowledge the importance of interpersonal relationships but specify that friendships with hosts are crucial for learning the skills of a new culture. From this perspective, it is postulated that cross-cultural problems arise because sojourners have difficulty negotiating daily social encounters. This is supported by Furnham and Bochner's (1982) findings that a significant relationship exists between culture distance and social difficulty in the host culture, and by Armes and Ward's research (1989), which demonstrates that increased contact with locals improves socio-cultural expertise.

\section{Social Cognition Model of Adjustment}

The social cognition approach has been less well developed than other approaches. It shifts the emphasis away from skills and highlights the importance of variables, such as attitudes, values, self-concept, expectations, and perceptions, in the cross-cultural adjustment process (Armes and Ward, 1989; Weissman and Furnham, 1987; Wong-Reiger, 1984). Armes and Ward (1989), for example, found that favorable attitudes towards the host country are associated with self-reports of psychological well-being. Also, ethnocentric attitudes are believed to impede sojourner adjustment (Brislin, 1981; Church, 1982). Although some researchers argue that a moderate amount of social distance may be conducive for good inter- group relations (Maretzki, 1969), it may be inferred from research on in-group/out-group dynamics that high degrees of social distance will exacerbate adjustment problems (Bochner, 1982; Jaspars and Hewstone, 1982).

\section{IV . Adjustment Issues of American and Japanes Expatriates}

Most of the scientific research that has studied the adjustment of managers working and living abroad has focused on Americans working overseas. Although recently, work has also been done on Japanese expatriates, the number of such 
studies is still limited compared to those done on American expatriates.

\section{Previous Studies on American Expatriates}

Most studies on American expatriates, to date, focused mainly on their managerial effectiveness in overseas positions (Tung, 1987; Black and Porter, 1991). Much of the emphasis of these studies has been to identify whether the assignment was considered a "success" or "failure." In these studies, the principal measures for the relative success or failure of an assignment were not indicators of expatriate efficiency, effectiveness, or adjustability. Rather, success or failure was measured based on statistics reporting dismissal from an assignment or early repatriation to the home country. These studies, while important, provided only limited information on the actual cross-cultural adjustment of expatriates.

Other studies focused on the determinants of expatriate satisfaction (Torbiorn, 1982) and adjustment (Black, 1990b; Black and Gregersen, 1991), their acculturation profile (Mendenhall and Oddou, 1985; 1986), the reasons for their high failure rates and ways of enhancing their success (Tung, 1987; 1988), and their work role transitions (Black, 1988). Still other studies focused on the organizational point of view (Misa and Fabricatore, 1979; Tung, 1981; 1988), rather than examine the problem from the perspective of the actual expatriates (Black, 1988; Torbiorn, 1982; Weissman and Furnham, 1987). In such studies, adjustment was not measured by soliciting the views of the actual expatriates; instead, the opinions of the corporate decision makers were sought regarding the adjustment of the expatriates within their companies. Clearly, assessing the adjustment of the expatriates through a third-party view can at times lead to inaccurate conclusions. In any case, most attention has been given to the areas of American expatriate personnel selection (Tung, 1981; Oddou and Mendenhall, 1984; 1985; Zeira and Banai, 1985; Mendenhall, Dunbar and Oddou, 1987; Abe and Wiseman, 1983; Stening, 1979; Hawes and Kealey, 1981; Church, 1982), training (Korn-Ferry International, 1981; Tung, 1981; Black and Mendenhall, 1990; Earley, 1987; Mendenhall and Oddou, 1985), and to a lesser extent, career pathing (Mendenhall et. al., 1987; Schein, 1971; 1978).

Black (1988), in a study of work role transitions of American expatriate managers in Japan, found support for the multi-faceted phenomenon of cross-cultural adjustment. Black and Gregersen (1991) examined the impact of job, personal, and general factors on the various facets of cross- cultural adjustment based on data collected from American expatriate managers on Pacific 
Rim assignments (Japan, Hong Kong, Korea, and Taiwan). Unlike Black (1988), Black \& Gregersen (1991) further subdivide adjustment to include a third dimension-interaction adjustment. The results of the study indicate that different antecedents were related to different facets of adjustment (see Table 1).

Table 1. A Summary of the Antecedents to the Cross-Cultural Adjustment of American and Japanese Expatriates.

\begin{tabular}{lcc}
\hline & American & Japanese \\
\hline (A) Antecedents to Work Adjustment & & \\
1. Role ambiguity & - & - \\
2. Role discretion & - & $\mathrm{NA}$ \\
3. Role conflict & + & + \\
4. Association with host nationals & $\mathrm{NA}$ & + \\
5. Motivation for overseas assignment & 0 & + \\
6. Spouse adjustment & - & + \\
7. Predeparture knowledge & + & $\mathrm{NA}$ \\
8. Prior overseas experience & & \\
(B) Antecedents to Interaction Adjustment & + & + \\
1. Spouse adjustment & $+/-$ & + \\
2. Predeparture knowledge & + & + \\
3. Association with host nationals & + & $\mathrm{NA}$ \\
4. Self-initiated cross-culture training (CCT) & + & $\mathrm{NA}$ \\
5. Company-provided CCT & & \\
(C) Antecedents to General Adjustment & + & + \\
1. Predeparture knowledge & + & + \\
2. Family/Spouse adjustment & + & 0 \\
3. Association with host nationals & $\mathrm{NA}$ & + \\
4. Motivation for overseas assignment & & + \\
5. Role discretion & + & \\
\hline
\end{tabular}

Note: + denotes positive relationship

- denotes negative relationship

+/- denotes both positive and negative relationships

0 denotes lack of any relationships

NA denotes not applicable (the variable has not been tested) 


\section{Previous Studies on Japanese Expatriates}

Very few studies have examined the adjustment of Japanese as sojourners in foreign countries. Abe and Wiseman (1983) studied the adjustment of 57 Japanese students who were studying in America and found that (1) the ability to communicate interpersonally, (2) the ability to adjust to different cultures, (3) the ability to deal with different social systems, (4) the ability to establish personal relationships, and (5) the ability to understand other people were rated by the 57 Japanese students as important personal dimensions for being able to adjust to living in America. However, there was no test to verify if indeed these dimensions were important. Tung's works $(1982,1984)$ are some of the earliest research on Japanese expatriates. However, her studies examined the policies and practices of 35 Japanese firms and did not study the adjustment of specific Japanese expatriates.

Black (1990c) studied the factors that relate to the adjustment of Japanese expatriates in America. He tested the relationship of various personal characteristics (cultural flexibility, social orientation, willingness to communicate, ethnocentricity, and conflict resolution orientation) to the three facets of adjustment (job, interaction, and general) for Japanese expatriate managers in America. The results provide tentative support for a three-faceted conceptualization of adjustment with five personal dimen- sions important in adjustment. With the exception of ethnocentricity, all personal dimensions were significantly related to the three facets of adjustment.

In another study, Black (1990a) examined the factors that relate to the adjustment of Japanese expatriate managers in America. Variables such as individual factors, job-related factors, non-work factors, and organiza- tional factors were tested for their relationships to the above three facets of cross-cultural adjustment. Different antecedents were again, found to be related to the different facets of adjustment, as in the case for the American sample (see Table 1).

\section{The Adjustment Pattern of American and Japanese Expatriates}

Very few studies seek to systematically compare American and Japanese expatriates. Among those few that did, comparisons were mainly made in the areas of failure rates, magnitude of difficulties encountered, and perceived satisfaction in functioning in the foreign cultures (Tung, 1982; 1987; Stening, 
1990; Stening and Hammer, 1992). These studies did not focus on the differences between American and Japanese expatriates in terms of adjustment to the three facets: job, interaction, and general non-working environment; of cross-cultural adjustment.

In her study, Tung (1982) found that a majority of Japanese firms had expatriate failure rates (expatriates who returned early from their overseas assignment) of less than 5 percent, while American firms had failure rates of between 10 and 40 percent. Tung (1982) also found that 57 percent of the Japanese firms in her sample provide pre-departure cross-culture training (CCT) compared to only 32 percent of the American firms. In both cases, training was related to a lower failure rate.

Reasons for the Failure of American and Japanese Expatriates Overseas

The principal reasons Tung(1988) found for the failure of American and Japanese expatriates in foreign cultures are as follows: (in descending order of importance)

\section{American Expatriates}

1. Inability of the manager's spouse to adjust to a different physical or cultural environment

2. Manager's inability to adapt to a different physical or cultural environment

3. Other family-related problems

4. Manager's personality or emotional immaturity

5. Manager's inability to cope with the responsibilities posed by overseas work

6. Manager's lack of technical competence

7. Manager's lack of motivation to work overseas

\section{Japanese Expatriates}

1. Inability of the manager to cope with the larger responsibilities posed by overseas work

2. Manager's inability to adapt to a different physical or cultural environment

3. Manager's personality or emotional immaturity

4. Manager's lack of technical competence for job assignments

5. Inability of the manager's spouse to adjust to a different physical or cultural environment

6. Manager's lack of motivation to work overseas

7. Other family-related problems 
As shown, problematic family situations and lack of relational skills (individual inability to deal effectively with clients, superiors, peers, and subordinates in a foreign environment) are the main reasons for American expatriate failure overseas. This highlights the crucial role in the U.S. sample of the family in influencing successful performance.

The rank ordering of reasons for failure cited by Japanese multinational companies (MNCs) is very different from that cited by their U.S. counterparts. For Japanese firms, the manager's inability to cope with the larger responsibilities posed by overseas work emerged as the most important factor for failure. Tung (1988) speculated that this could stem from unique characteristics of the Japanese management system, but did not provide further explanation.

Unlike American expatriates, spouse factor was not found to be important in accounting for the failure of Japanese expatriates. This does not come as a surprise considering the role and status Japanese culture relegates to the spouse. According to Tung (1987), Japanese wives are generally more obedient and dependent than American wives. Given the greater emphasis on face-saving, a Japanese woman would not want to fail in her role as a wife by complaining about the problems encountered while living in a foreign country.

Tung (1984) speculated on two causes for the lower failure rates in the Japanese sample. Firstly, the lower rate might be due to the fact that Japanese expatriates actually adjust better to their assignments than their Americans counterparts. However, the researcher is of the view that failure rate should not, strictly speaking, be used as a proxy for adjustment. This is because failure rates may reflect the difference in the conditions of the internal and external labor market and career patterns in the respective MNCs. Nevertheless, one should bear in mind that failure rate does correlate with adjustment; an expatriate who experiences great difficulty in adjusting to the foreign culture generally has a higher probability of failing the assignment.

Alternatively, there may be differences in human resource policies and practices between U.S. and Japanese firms that account for the differences in American and Japanese expatriates' adjustment ability. Based on the interviews conducted by Tung (1987), the following list highlights several apparent common denominators to successful performance among Japanese multinationals.

1. Their long-term orientation regarding overall planning and performance assessment

2. Use of more rigorous training programs to prepare candidates for overseas assignments 
3. Provisions of a comprehensive expatriate support system

4. Overall qualification of candidates for overseas assignment

5. Restricted job mobility

\section{Inter-Cultural Effectiveness of American and Japanese Expatriates}

Stening (1990) examines the difficulties confronted by American and Japanese expatriates in Thailand. The results show that there are differences in the magnitude of the difficulties encountered by American and Japanese in adapting to particular aspects of life in Thailand. However, somewhat surprisingly, both groups of expatriates shared a remarkably similar perspective on the nature and relative importance of the difficulties. In assessing American and Japanese managers's self- perceptions of their abilities to adjust to their assignment in Thailand, it was found that there are significant differences between the means of the two groups on 13 of 24 ability items. Americans felt significantly more able than Japanese with respect to 12 of these items: (1) dealing with unfamiliar situations, (2) changes in lifestyle, (3) financial difficulties, (4) different political systems, (5) different social customs, (6) unforeseen problems, (7) entering into meaningful dialogue with others, (8) different communication systems, (9) different educational systems, (10) under- standing the feelings of others, (11) empathizing with another person, and (12) effectively working with other people. The only item on which Japanese felt more able than American was "communicating in Thai." These findings seem to suggest that the American expatriates's degree of satisfaction and their view of their own effectiveness in Thailand were significantly greater than that of their Japanese counterparts. This result seems to confirm Tung's speculations that failure rates may reflect the difference in the conditions of the internal and external labor market and career patterns of the MNCs and that the differences in human resource policies and practices between U.S. and Japanese firms account for the differences in American and Japanese expatriates' adjustment ability.

\section{Important Abilities Ranked by American and Japanese Expatriates}

In the same study (Stening, 1990), American and Japanese expatriates' views on the importance of various abilities were assessed. The two groups are quite in agreement with each other on the important abilities. This suggests that similarities do exist between these two groups of culturally distinct expatriates. 


\section{American expatriates}

Ability to...

(1) work effectively with other people

(2) cope effectively with frustration

(3) deal effectively with communication misunderstandings

(4) understand accurately the feelings of others
Japanese expatriates

Ability to...

(1) deal effectively with stress

(2) understand accurately the other's point of view

(3) work effectively with other people

(4) cope effectively with frustration

\section{Attitudinal Differences between American and Japanese Expatriates}

Stening and Hammer (1992) found that Japanese and American managers differ significantly in their attitudinal satisfaction regarding living in a foreign culture, perceived effectiveness in functioning well in a foreign culture, and judged intercultural abilities in managing stress, communicating effectively, and developing satisfying relationships. These findings also suggest that, from the respondents' own assessments, Japanese managers had less favorable attitudes toward their intercultural experience and their social skills compared to American managers. When comparing the perceptions of American managers and Japanese managers in Thailand, it was found that the Japanese perceived themselves as (1) significantly less satisfied with living in the host culture, (2) significantly less effective in functioning in the host culture, and (3) significantly lower in their ability to establish intercultural relationships. The root of these differences may lie in the different cultural and historical traditions of each country (Linowes, 1993); that is, while Americans were exposed to cultural and ethnic diversity due to waves of immigrants who came in search of better opportunities, Japanese historically lived in a self- contained fashion with a large, homogeneous population based in communal villages and urban settings.

\section{V . Conclusion}

In conclusion, empirical studies have been limiting by focusing on the failure rates of expatriates rather than on their adjustment capacity in foreign societies. Few studies have attempted to assess the level of adjustment for both American and Japanese expatriates in the same cultural environment; it is therefore not possible to come up with definite, conclusive similarities and differences between 
the two groups with respect to adjustment. Future studies need to investigate the adjustment capacity of American and Japanese expatriates through systematic and longitudinal observation of (1) how much more well- adjusted one group of expatriates is over the other in various cultures, (2) the differences in their adjustment capabilities with respect to different facts of cross cultural adjustment, (3) the factors that enable one group to outperform the other group, and (4) the impact of different work patterns and human resource policies of American and Japanese MNCs on adjustment capability of their expatriates.

\section{References}

Abe, H. \& Wiseman, R.L. "A cross-cultural confirmation of the dimensions of intercultural effectiveness." International Journal of Intercultural Relations, 7, 1983, pp. 53-68.

Adelman, M.B. "Cross-cultural adjustment: a theoretical perspective on social support." International Journal of Intercultural Relations, 12. 1988, pp. 183-204.

Armes, K. \& Ward, C. "Cross-cultural transitions and sojourner adjustment in Singapore." Journal of Social Psychology, 129. 1989, pp. 273-275.

Baker, J. C. \& Ivancevich, J.M. "The assignment of American executives abroad: systematic, haphazard or chaotic?" California Management Review, 13. 1971, pp. 39-44.

Black, J.S. "Work role transitions: a study of American expatriate managers in Japan." Journal of International Business Studies, 19. 1988, pp. 277-294.

Black, J.S. "Factors related to the adjustment of Japanese expatriate managers in Japan." Research in Personnel and Human Resources Management, 5, Suppl. 2. 1990a, pp. 109-125.

Black, J.S. "Locus of control, social support, stress and adjustment to international transfers." Asia Pacific Journal of Management, 7. 1990b, pp. $1-29$.

Black, J.S. "The relationship of personal characteristics with the adjustment of Japanese expatriate managers." Management Interna- tional Review, 30. 1990c, pp. 119-134.

Black, J.S. \& Gregersen, H.B. "Expectations, satisfaction and intention to leave of American expatriate managers in Japan." International Journal of Intercultural Relations, 14. 1990, pp. 485-506. 
Black, J.S. \& Gregersen, H.B. "Antecedents to cross-cultural adjustment for expatriates in Pacific Rim assignments." Human Relations, 44, 1991, pp. 497-515.

Black, J.S., Gregersen, H.B. \& Mendenhall, M.E. Global Assignments: Successfully Expatriating and Repatriating International Managers. San Francisco: Jossey Bass, 1992.

Black, J.S. \& Mendenhall, M.E. "Cross-cultural training effectiveness: a review and a theoretical framework for future research." Academy of Management Review, 15. 1990, pp. 113-136.

Black, J.S. \& Stephens, G.K. "The influence of the spouse on American expatriate adjustment and intent to stay in Pacific Rim overseas assignments." Journal of Management, 15. 1989, pp. 529-544.

Bochner, S. "The social psychology of cross-cultural relations." In S. Bochner (Ed.), Cultures in Contact. New York, NY: Pergamon, 1982, pp. 5-44.

Bock, P.K. (Ed.) Culture Shock, a Reader in Modern Anthropology. New York, NY: Alfred A. Knopf Inc., 1970.

Brein, M. \& David, K.H. "Intercultural communication and the adjustment of the sojourner.” Psychology Bulletin, 76. 1971, pp. 215-230.

Brislin, R.W. Cross-Cultural Encounters: Face-to-Face Interaction. New York, NY: Pergamon, 1981.

Church, A.T. "Sojourner adjustment." Psychological Bulletin, 9. 1982, pp. 540572.

Copeland, L. \& Griggs, L. Going International. New York, NY: Random House, 1985.

Earley, P.C. "Intercultural training for managers: a comparison of documentary and interpersonal methods." Academy of Management Journal, 30. 1987, pp. 685-698.

Feinstein, B.E.S. \& Ward, C. "Loneliness and psychological adjustment of sojourners: new perspectives on culture shock." In D., M. Keats, D. Munro \& L. Mann (Eds.), Heterogeneity in Cross-Cultural Psychology. Lisse: Swets \& Zeutlinger, 1990, pp. 537-557.

Fiedler, F., Mitchell, T. \& Triandis, H. "The culture assimilator: an approach to cross-cultural training." Journal of Applied Psychology, 55. 1971, pp. 95102.

Fontaine, G. "Roles of social support systems in overseas relocations: implication for intercultural training." International Journal of Intercultural Relations, 10. 1986, pp. 361-378. 
Furnham, A. \& Bochner, S. "Social difficulty in a foreign culture: an empirical analysis of culture shock." In S. Bochner (Ed.), Cultures in Contact, Oxford: Pergamon, 1982, pp. 161-198.

Furnham, A. \& Bochner, S. Culture Shock: Psychological Reactions to Unfamiliar Events. New York: Methuen, 1986.

Gudykunst, W.B. \& Hammer, M.R. "Basic training design: approaches to intercultural training." In D. Landis \& R.W. Brislin (Eds.), Handbook of Intercultural Training: Issues in Theory and Design, 1. New York, Pergamon, 1983, pp. 118-154.

Gullahorn, J. R. \& Gullahorn, J.E. "An Extension of the U-curve hypothesis." Journal of Social Issues, 3, 1963, pp. 33-47.

Gullick, C.J.M.R. "Managing culture shock: ethnography of expatriate British executives." Paper presented at the $12^{\text {th }}$ International Congress of Anthropological \& Ethnological Sciences. Zagreb, Yugoslavia, 1988.

Hall, E.T. The Silent Language. New York, Doubleday, 1959.

Harris, P.R. \& Moran, R.T. Managing Cultural Differences. Houston, TX: Gulf Publishing, 1989.

Hawes, F. \& Kealey, D.J. "An empirical study of Canadian technical assistance." International Journal of Intercultural Relations, 5, 1981, pp. 239-258.

Jaspars, J. \& Hewstone, M. "Cross-cultural interaction, social attribution and intergroup relations." In S. Bochner (Ed.), Culture in Contact: Studies in Cross-Cultural Interaction. Oxford, Pergamon, 1982.

Klineberg, O. \& Hull, W. At a Foreign University: An International Study of Adaptation and Coping. New York, Praeger, 1979.

Korn-Ferry International $A$ Study of the Repatriation of the American International Executive. New York, Korn-Ferry International, 1981.

Lee, Y. \& Larwood, L. "The socialization of expatriates in Multinational firms." Academy of Management Journal, 26. 1983, pp. 657-665.

Linowes, R.G. "The Japanese manager's traumatic entry into the United States: understanding the American-Japanese cultural divide." Academy of Management Executive, 7(4). 1993, pp. 21-38.

Lundstedt, S. "An introduction to some evolving problems in cross- cultural research." Journal of Social Issues, 19. 1963, pp. 1-9.

Lysgaard, S. "Adjustment in a foreign society: Norwegian Fulbright grantees visiting the U.S." International Social Science Bulletin, 7. 1955, pp. 45-51.

Maretzki, T. "Transcultural adjustment of peace corps volunteers." In J.Finney (Ed.), Culture Change, Mental Health \& Poverty. Lexington: University of 
Kentucky Press, 1969

Mendenhall, M. \& Oddou, G. "Acculturation profiles of expatriate managers: implications for cross-cultural training programs." Columbia Journal of World Business, 21(4), 1986, pp. 73-79.

Mendenhall, M. Dunbar, E. \& Oddou, G. "Expatriate selection, training and career pathing: a review and critique." Human Resource Management, 26, 1987, pp. 331-345.

Misa, K.F. \& Fabricatore, J.M. "Return on Investment of Overseas Personnel." Financial Financial Executive, 47, 1979, pp. 42-46.

Mischel, W. "Predicting the success of peace corps volunteers in Nigeria." Journal of Personality \& Social Psychology, 1, 1965, pp. 510-517.

Nicholson, N. "A theory of work role transitions." Administrative Science Quarterly, 29, 1984, pp. 172-191.

Oberg, K. "Culture shock: adjustment to new cultural environments." Practical Anthropology, 7, 1960, pp. 177-182.

Prutti, F. "The adaptation of African students to American society." International Journal of Intercultural Relations, 2, 1978, pp. 90-118.

Randolph, G., Landis, D., \& Tzeng, O. "The effects of time and practice on culture assimilator training." International Journal of Intercultural Relations, 1, 1977, pp. 105-119.

Schein, E.H. "The individual, the organization, and the career: a conceptual scheme." Journal of Applied Behavioral Science, 7, 1971, pp. 401-426.

Schein, E.H. Career Dynamics: Matching Individual and Organizational Needs. Reading, MA: Addison Wesley, 1978.

Searle, W. \& Ward, C. "The impact of value discrepancies and cultural identity on psychological and sociocultural adjustment of sojourners." International Journal of Intercultural Relations, 15, 1990, pp. 209-225.

Sewell, W.H. \& Davidsen, O.M. "The adjustment of Scandinavian students." Journal of Social Issues, 12, 1956, pp. 9-19.

Sewell, W.H. \& Davidsen, O.M. Scandinavian Students on an American Campus. Minneapolis: University of Minnesota Press, 1961.

Stening, B.W. "Problems in cross-cultural contact: a literature review." International Journal of Intercultural Relations, 3, 1979, pp. 269-313.

Stening, B.W. "The adaptation of expatriate American and Japanese managers to Thailand." International Human Resource Management Review, 1, 1990, pp. 1-12.

Stening, B.W. \& Hammer, M.R. "Cultural baggage and the adaptation of 
expatriate American and Japanese managers." Management International Review, 32. 1992, pp. 77-89.

Torbiorn, R.L. Living Abroad: Personal Adjustment and Personnel Policy in the Overseas Setting. New York: John Wiley \& Sons, 1982.

Tung, R.L. "Selection and training of personnel for overseas assignment." Columbia Journal of World Business, 16. 1981, pp. 68-78.

Tung, R.L. "Selection and training procedures of U.S., European, and Japanese multinationals." Califormia Management Review, 25, 1982, pp. 57-71.

Tung, R.L. "Expatriate assignments: enhancing success and minimizing failure." Academy of Management Executive, 1, 1987, pp. 117-125.

Tung, R.L. The New Expatriates: Managing Human Resource Abroad. New York: Ballinger, 1988

Weissman, D. \& Furnham, A. "The expectations and experiences of a sojourning temporary resident abroad: a preliminary study." Human Relations, 40, 1987, pp. 313-326.

Wong-Reiger,D. "Testing a model of emotional and coping responses to problems in adaptation: foreign students at a Canadian university." International Journal of Intercultural Relations. 8, 1984, pp. 153-184.

Zeira, Y. \& Banai, M. "Selection of managers for foreign posts." International Studies of Management and Organization, 15, 1985, pp. 33-51. 